\author{
Péter Csavajda \\ Assistant lecturer- \\ Széchenyi István University \\ Department of Logistics and Forwarding \\ Hungary \\ Péter Böröcz \\ Associate professor \\ Széchenyi István University \\ Department of Logistics and Forwarding
}

\section{Experimental Study on Vibration Transmissibility of Pre-loaded XPE and PE Packaging Cushioning Material}

Most of the shipped products are sensitive against shock and vibration events during the distribution. Various cushioning materials are usually used to prevent the product damages. During the design process the protective packaging system is developed by the engineers based on the cushion and vibration transmissibility features (ie. cushion curve) of the material used. However, after the assembly of the packaged-product, these are stored for various long periods in warehouse. During this time the products pre-load the cushioning material and its parameters can be changed. The main goal of this study is to evaluate the vibration transmissibility of PE and XPE cushioning material at varied storage (preloaded) time and static load conditions. Four different kinds of duration (1 hour, 10 hours, 100 hours and 1000 hours) were used for the pre-loading period at three different static loads $(3.488 \mathrm{kPa}, 4.651 \mathrm{kPa}$, and 6.976 $\mathrm{kPa}$ ), and then at $0.5 \mathrm{oct} / \mathrm{min}$ sine sweep vibration the peak frequencies of response and vibration transmissibility, and damping ratio were determined. The results show that the effect of pre-loading is minimal by $P E$ material, but can influence the resonance frequencies by XPE cushioning material. The findings of this study help the packaging engineers to understand better the mechanism of these cushioning materials and to design suitable protective packaging systems.

Keywords): pre-loading, XPE (cross-linked polyethylene); PE (polyethylene); packaging; vibration transmissibility

\section{INTRODUCTION}

Vibration and shock may cause significant product damage during shipping of packaged products. Packaging systems are designed and developed to reduce and avoid these hazards. One of the primary hazards is the resonance, which has the potential to damage the product or the critical elements of the product due to the repetitive application of impacts. Therefore, the complete understanding of the shipping environment and the response of the cushioning material to this environment is required.

In general, the cushioning material in any packaging system gives a necessary isolation between the packaged item and the container. This can be modelled as a critical element attached to the product by a spring and a damper (Figure 1a and 1b). This protection element in the packaging system is known as a package cushion and usually is applied using plastic foams [1,2]. The usual packaging material is for cushioning a kind of lightweight, inexpensive material and holds a high strength-to-weight ratio and stiffness-to-weight ratio that has favourable cushioning characteristics and vibration transmissibility. These materials usually are plastic foam and paper packaging and have been widely

Received: June 2021, Accepted: August 2021

Correspondence to: Dr. Péter Böröcz, Széchenyi István

University, Department of Logistics and Forwarding,

Egyetem sqr. 1, Győr, 9026, Hungary.

E-mail: boroczp@sze.hu

doi:10.5937/fme2104962C

(C) Faculty of Mechanical Engineering, Belgrade. All rights reserved applied in secondary (master) and tertiary (transportation) packaging to protect products such as medical or electronic devices and instruments, or fragile products, etc. [3-5]. Foams are also applied by other industries; these materials have significant effect on the ride comfort in the vehicle seats [6-9].

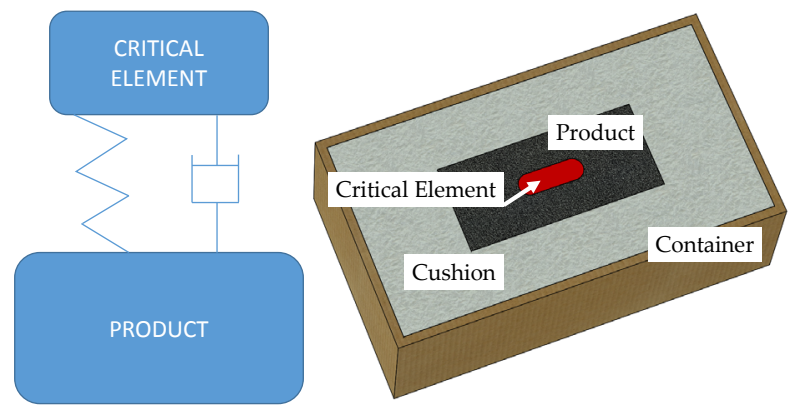

Figure 1a, b. The conceptual structure of packaging system using cushion material

After the packing process, the packaged-product is usually stored for a while before it will be shipped to the temporary or final destination. During this storage the mechanical properties of the cushion material can be influenced due to the static load of the product.

Previous research on PE materials cushioning characteristics focused mainly on the shock absorption properties [10], compression stress properties [11], and determining stress-energy based cushion curves [11-14]. Ref 14 and ref 15 also observed the temperature effect on the vibration transmissibility properties. Two research studied vibration transmissibility for packaging cushion 
using sine sweep, but not for PE foams, instead it used experimental paperboard materials $[3,16]$.The mechanical properties of cushion material were evaluated in both static and impact loading conditions by several authors [17-19]. The resonance behavior of cushioning materials was studied and mathematical models were developed by Parker and Batt [20, 21].

However, the authors of this paper could not find any published laboratory cushioning research that measures and analyzes the vibration transmissibility and damping ratios of $\mathrm{PE}$ or XPE for packaging cushion with various pre-loading conditions. Therefore, this paper presents new measured and analyzed data that can help packaging engineers to gain a better understanding of the characteristics of these materials and for designing appropriate protective packaging for sensitive goods.

The final goal of this study is to present the effect of pre-compression or pre-loading on cushioning features of foams to the critical frequency bands and damping ratios of $\mathrm{PE}$ and XPE cushion materials beside real circumstances as preloading. This paper also analyzes the effect of the pre-compression period and gives relevant information for varied static loads along them. This new data can be a useful technical support for packaging engineers in packaging design.

In the remainder of the paper first an overview of the materials and test methods are presented (Section 2), then the details of pre-compression of the samples are shown, as well as the applied testing equipment and static loads. Methods for determination of vibration transmissibility and estimation of damping ratios are also presented in this section. In Section 3 the results are provided and compared with the result of previous studies. This section also discusses the implications of the result in the package design process. Section 4 provides concluding remarks and future directions of the study.

\section{MATERIALS AND METHOD}

\subsection{Experimental materials}

Two types of PEs and one type of XPE closed-cell foams were used for this study.

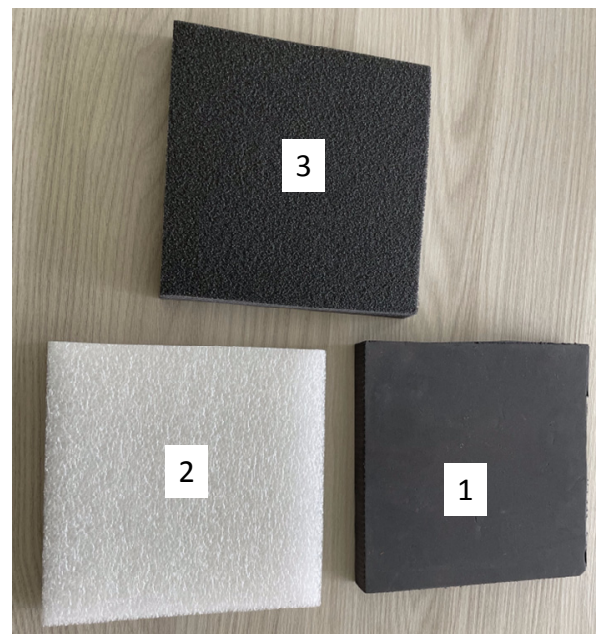

Figure 2. Foams used for this study, 1) XPE 30, 2) PE 25 and 3) PE30
Figure 2 shows the samples. The densities of $\mathrm{PE}$ foams were $25.25 \mathrm{~kg} / \mathrm{m}^{3}$ (PE25) and $30.12 \mathrm{~kg} / \mathrm{m}^{3}$ (PE30), and with a density of $29.55 \mathrm{~kg} / \mathrm{m}^{3}$ for XPE foam. The samples were cut into blocks with dimensions of $150 \mathrm{~mm}$ x $150 \mathrm{~mm}$ x $20 \mathrm{~mm}$ (length $\times$ width $\mathrm{x}$ thickness) by Green Packaging Ltd (supplier).

The microscope images $(\mathrm{N}=1 \mathrm{x})$ of the microstructure of the investigated foam materials can be seen in Figure 3.

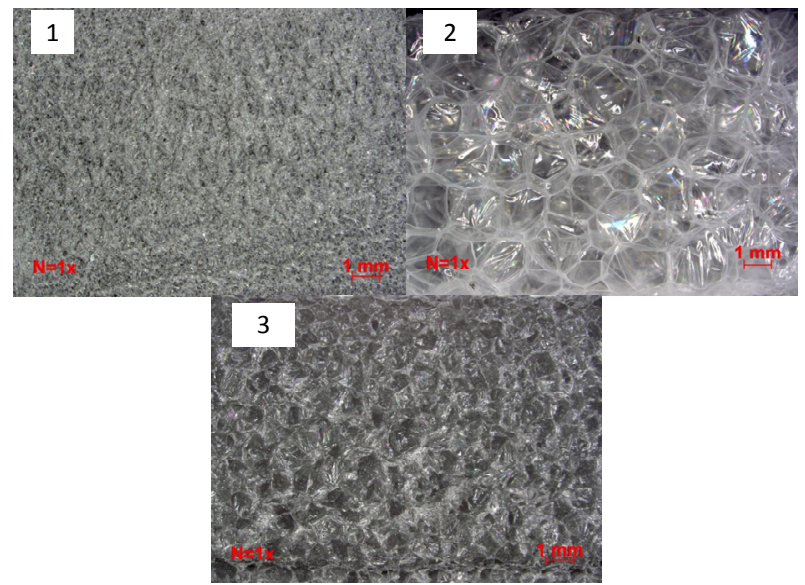

Figure 3. Scanning electron microscope images of the foams of this study, 1) XPE, 2) PE 25 and 3) PE 30

\subsection{Method for pre-loading}

Before each test, the test samples were pre-compressed for 1, 10, 100 and 1000 hours with different static loads at 20 temperature and this temperature condition was maintained during the entire measurement process. The static loads were $3.488 \mathrm{kPa}, 4.651 \mathrm{kPa}$, and $6.976 \mathrm{kPa}$ by weighted concrete mass blocks. The blocks were placed to the top of the foam and then a fixture was clamped to hold the static load in the required centered position. The same static load was maintained during the vibration test.

\subsection{Method for vibration transmissiblity}

The theory of vibration transmissibility for cushioning material of packages is generally described as the ratio of the force transmitted to the force applied at different static loads [22]. Transmissibility is a non-dimension ratio of output to input vibration of the packaged product.

Figure 4 shows the test system of this measurement containing a TIRA TV59355AIT electrodynamic vibration tester, a VR 9500 vibration testing controller and an acquisition system with a software VibrationView for the processing of the measurement. During the measurements one acceleration sensor controlled the excitation input at the platform of the vibration head expander, and another sensor was attached to the mass block to measure the response acceleration.

The details of the vibration test setup for all measurements was sine sweep at $0.5 \mathrm{oct} / \mathrm{min}$ with an amplitude of $0.5 \mathrm{~g}$ (zero-to-peak). The frequency range was 3 to $300 \mathrm{~Hz}$ by fitting to the most common test standards for transportation simulation of goods, because the most common and relative high amplitude vibration can be found at this frequency band. 
The measured acceleration data were analyzed and presented in the form of vibration transmissibility and frequency curve. Then, after the series of tests, the vibration transmissibility and frequency curves at different static loads were evaluated. The numerical results for resonance frequency bands, and their values, are naturally reported for this study.

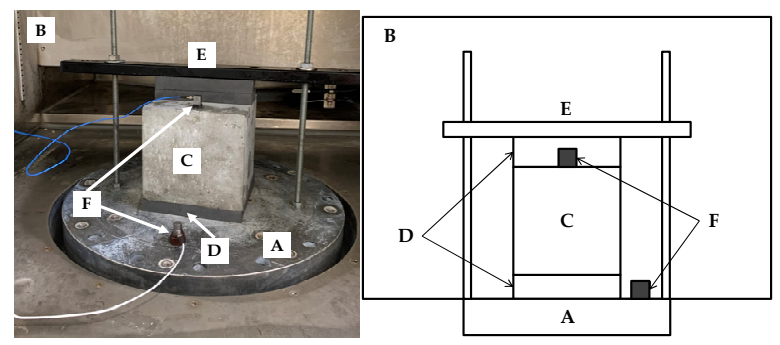

Figure 4. The measurement system used in this study (a) vibration system, (b) climate chamber, (c) concrete block, (d) test specimen, (e) fixtures and (f) acceleration sensors

\subsection{Method for estimation of damping ratio}

The transmissibility value $\left(T_{r}\right)$ for a linear spring-mass system with single degree of freedom system with viscous damping may be calculated from the following equation using Fourier transform of equation of motion [23].

$$
T_{r}=\sqrt{\frac{1+\left[2 \xi\left(\frac{f_{f}}{f_{n}}\right)^{2}\right]}{\left[1-\left(\frac{f_{f}}{f_{n}}\right)^{2}\right]+\left[2 \xi\left(\frac{f_{f}}{f_{n}}\right)^{2}\right]}}
$$

where $f_{f}$ is the forcing frequency $[\mathrm{Hz}], f_{n}$ is the natural frequency $[\mathrm{Hz}]$ and $\xi$ is the damping ratio. When $f_{f} \cong f_{n}$ the damping ratio can be estimated from Equation (1) [24]

$$
\xi=\frac{1}{2} \times \sqrt{\frac{1}{T_{r}^{2}-1}}
$$

When $T_{r} \gg 1$ the damping ratio can be estimated from Equation (2) [24]

$$
\xi \cong \frac{1}{2 T_{r}}
$$

As a summary of this section, the evaluation of the effects of pre-compression on vibration transmissibility is the following.

1. Preparation of samples and mass blocks (size, weight, number)

2. Pre-compression of samples (static load, time)

3. Assembly of test measurement system (fixture, static stress)

4. Parameter setting for vibration measurement (frequency band; sweep rate; amplitude; frequency range;

5. Calculation and analysis of measured result (applied equations; units).

\section{RESULTS AND DISCUSSION}

\subsection{Experimental results}

On the pre-compressed cushion materials according to the test method defined in Section 2, the sine sweep tests were performed. Frequency ranges and vibration transmissibilities were measured from vibration tests directly. Vibration transmissibility and frequency curves of the tested cushion materials are shown in Figure 5-7. The curves with different pre-loading duration of PE 25 at static loads $3,488 \mathrm{kPa}, 4,651 \mathrm{kPa}$ and $6.976 \mathrm{kPa}$ can be see in Figure 5. Figure 6 and 7 provide the same for PE30 and for XPE materials.

The damping ratios were calculated from the experimental data by Equation (2) and Equation (3). Both experimental and calculated values can be seen in Table 1 to Table 3 . Each table separately provides the experimental results of PE25, PE 30 and XPE cushion materials at different temperatures and at different static loads such as $3.488 \mathrm{kPa}, 4.651 \mathrm{kPa}$, and $6.976 \mathrm{kPa}$.

\subsection{Findings from the Experimental Results}

By comparing and analyzing the experimental results of vibration transmissibility and frequency curves of the pre-loaded PE25, PE30 and XPE cushion materials at different static loads the following observations may be discussed.

a) The result of PE25 and PE30 show a minimal influence of the duration of pre-compression to the transmissibility plots. The maximum changes of the resonant frequency were $10 \%$ at all static loads. The effect of pre-loading of XPE shows a stronger influence when compared with PE25 and PE30. The resonant frequency values were between $80.9064 \mathrm{~Hz}$ and 94.6497 $\mathrm{Hz}$ at $3.488 \mathrm{kPa}$, moved from $61.3398 \mathrm{~Hz}$ to $79.4268 \mathrm{~Hz}$ at $4.651 \mathrm{kPa}$ and changed from $46.078 \mathrm{~Hz}$ to $58.0356 \mathrm{~Hz}$ at $6.976 \mathrm{kPa}$.

b) The duration of static load does not influence the effect of the static loads value. When the value of the static load is increased, the value of the resonant frequency is decreased by all investigated materials at all static loads and at all durations of pre-loading.

c) Over $55 \mathrm{~Hz}$ the attenuation zone of PE25 was reached at all pre-loading. This value was $86 \mathrm{~Hz}$ and $126 \mathrm{~Hz}$ for PE30 and for XPE.

d) $54.9094 \mathrm{~Hz}$ was the start point of the attenuation zone of PE25 at $3.488 \mathrm{kPa}$ for pre-loading of 1, 10 and 1000 hours. This value was $51.4743 \mathrm{~Hz}$ for pre-loading of 100 hours.

e) XPE has the same resonant frequency value $(80.9064 \mathrm{~Hz})$ at $3.488 \mathrm{kPa}$ static load for pre-loading of 10 and 100 hours.

f) The average value of transmissibility was influenced by the duration of the pre-loading only by XPE. The deviation from the average was under $5 \%$ of all other materials. The values are summarized in Table 2. 

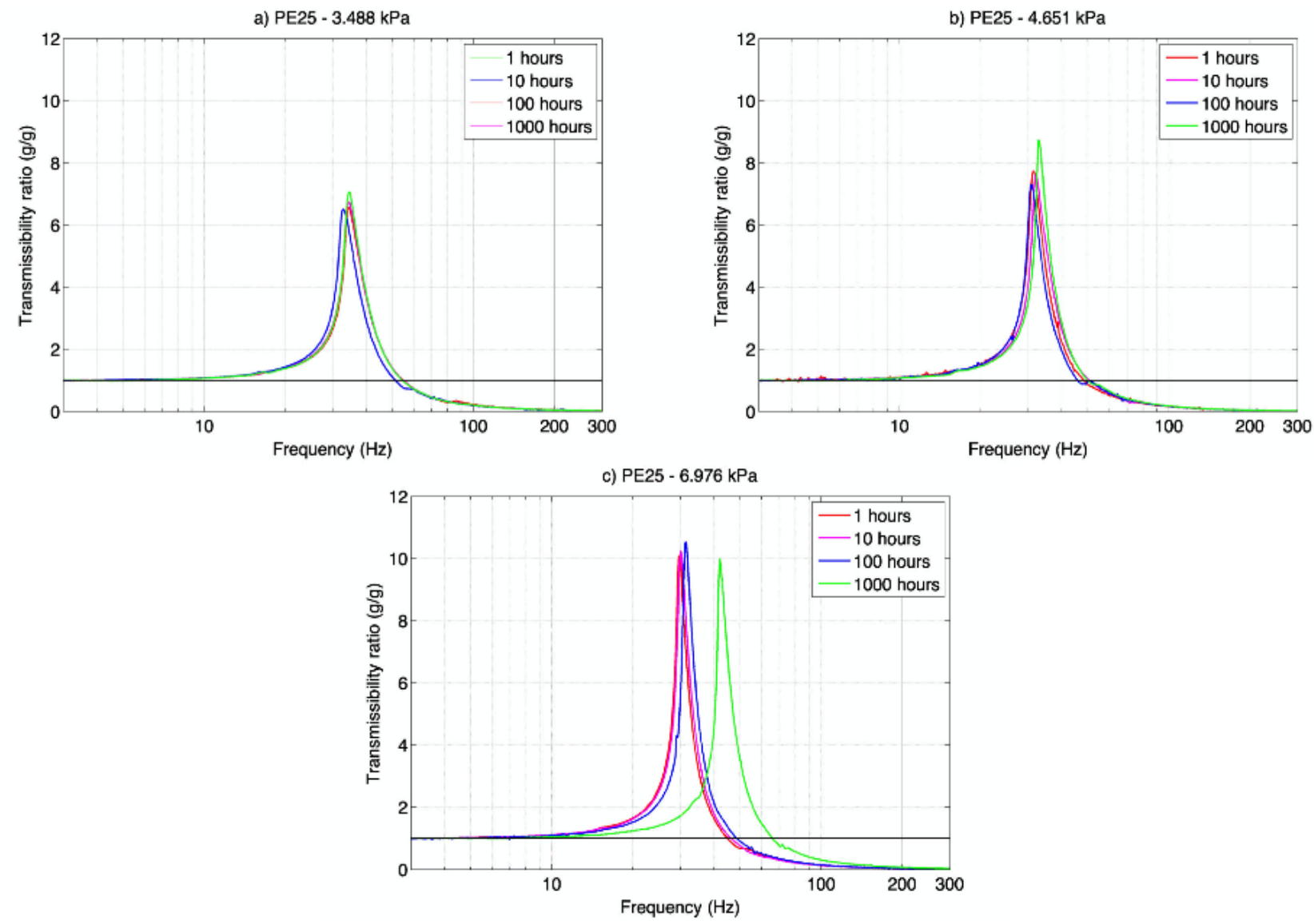

Figure 5. Vibration transmissibility and frequency curve for (a) PE25 at a static load of $3.488 \mathrm{kPa}$, for (b) PE25 at a static load of $4.651 \mathrm{kPa}$, for (c) PE25 at a static load of $6.976 \mathrm{kPa}$

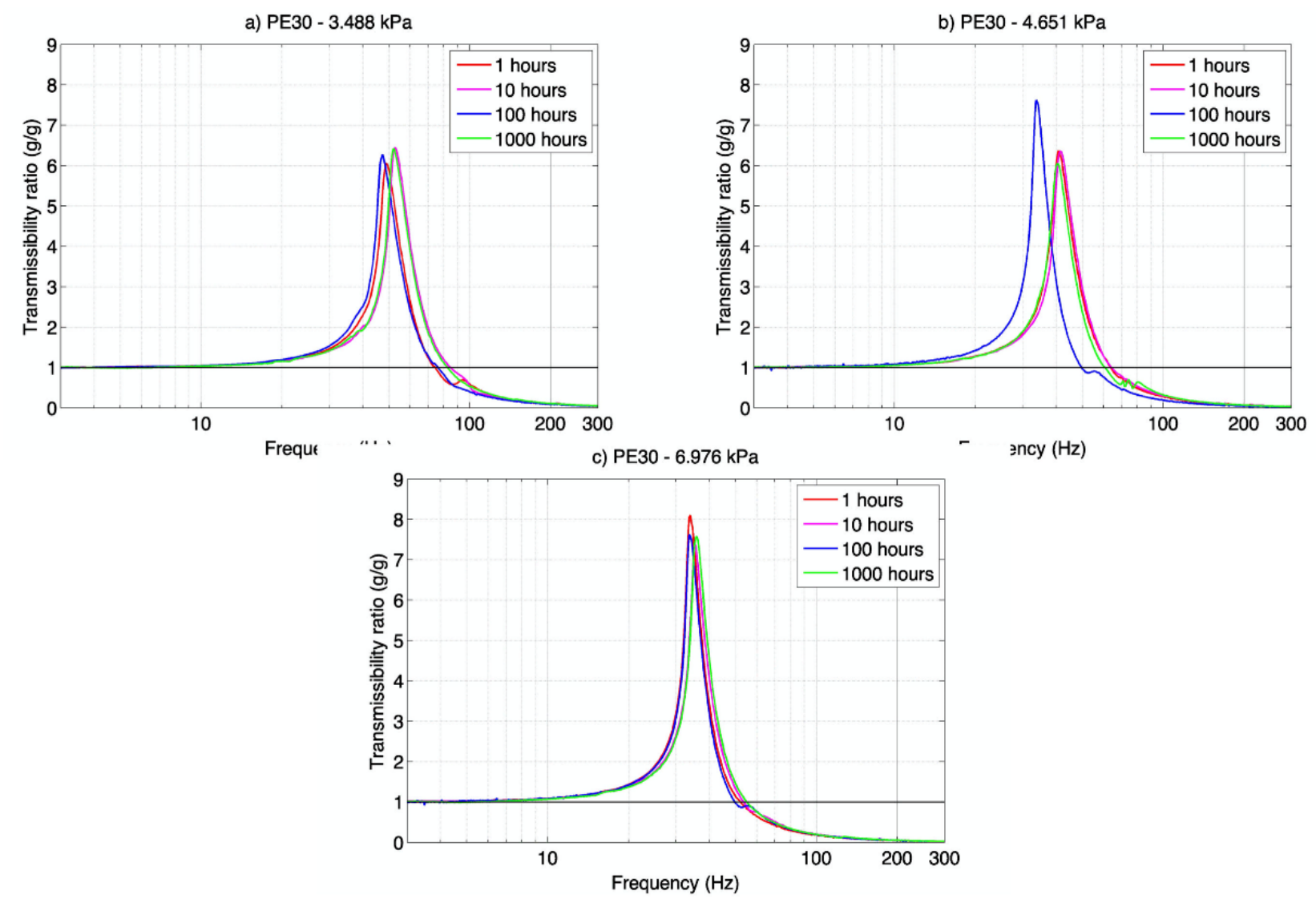

Figure 6. Vibration transmissibility and frequency curve for (a) PE30 at a static load of $3.488 \mathrm{kPa}$, for (b) PE30 at a static load of $4.651 \mathrm{kPa}$, for (c) PE30 at a static load of $6.976 \mathrm{kPa}$ 

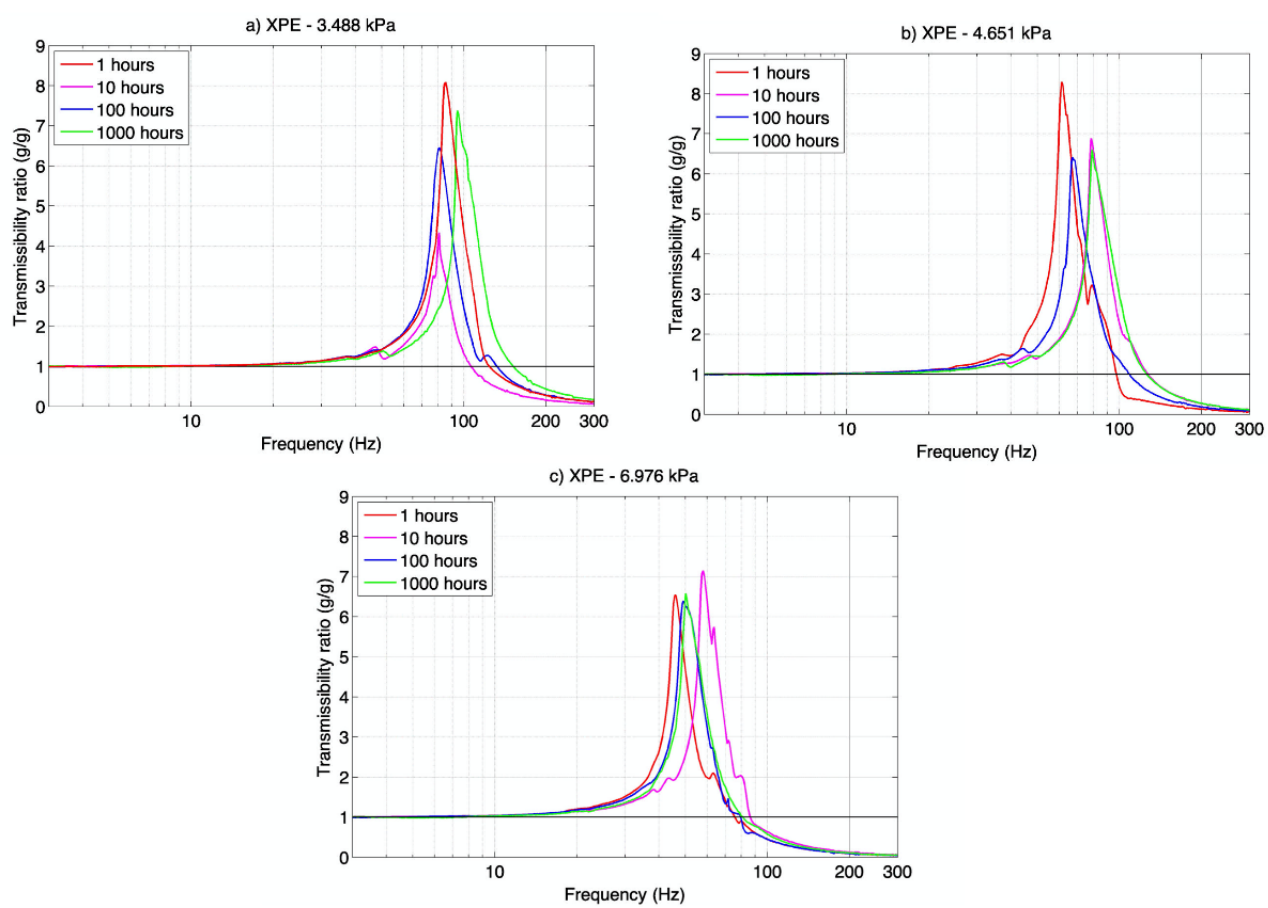

Figure 7. Vibration transmissibility and frequency curve for (a) XPE at a static load of $3.488 \mathrm{kPa}$, for (b) XPE at a static load of $4.651 \mathrm{kPa}$, for (c) XPE at a static load of $6.976 \mathrm{kPa}$

Table 1. Vibration transmissibility and damping ratio of PE25, PE30 and XPE cushion materials

\begin{tabular}{|c|c|c|c|c|c|c|c|c|c|c|}
\hline $\begin{array}{c}\text { Duration } \\
\text { of Static } \\
\text { Load } \\
\text { [hours] }\end{array}$ & $\begin{array}{c}\text { Static } \\
\text { load } \\
{[\mathrm{kPa}]}\end{array}$ & $\begin{array}{c}\text { Frequency } \\
\text { Range of } \\
\text { PE } 25 \\
{[\mathrm{~Hz}]}\end{array}$ & $\begin{array}{l}\text { Transmissibility } \\
\text { of PE25 }\end{array}$ & $\begin{array}{c}\text { Damping } \\
\text { ratio of } \\
\text { PE25 }\end{array}$ & $\begin{array}{c}\text { Frequency } \\
\text { Range of } \\
\text { PE30 } \\
{[\mathrm{Hz}]}\end{array}$ & $\begin{array}{l}\text { Trans. } \\
\text { of } \\
\text { PE30 }\end{array}$ & $\begin{array}{c}\text { Damping } \\
\text { ratio of } \\
\text { PE30 }\end{array}$ & $\begin{array}{l}\text { Frequency } \\
\text { Range of } \\
\text { XPE }[\mathrm{Hz}]\end{array}$ & $\begin{array}{l}\text { Trans. } \\
\text { of } \\
\text { XPE }\end{array}$ & $\begin{array}{c}\text { Damping } \\
\text { ratio of } \\
\text { XPE }\end{array}$ \\
\hline \multirow{9}{*}{1} & \multirow{3}{*}{3.488} & 11.5423 & 1.1015 & 1.0828 & 15.6515 & 1.1024 & 1.0778 & 26.2425 & 1.1028 & 1.0744 \\
\hline & & 34.2955 & 6.5726 & 0.0761 & 49.153 & 6.0573 & 0.0825 & 85.5128 & 8.0871 & 0.0618 \\
\hline & & 54.9094 & 0.9907 & & 75.1482 & 0.9514 & & 124.842 & 0.9681 & \\
\hline & \multirow{3}{*}{4.651} & 9.9578 & 1.1008 & 1.0864 & 13.256 & 1.1002 & 1.0897 & 19.8959 & 1.1022 & 1.0787 \\
\hline & & 31.5621 & 7.7097 & 0.0649 & 40.8686 & 6.3715 & 0.0785 & 61.3398 & 8.2944 & 0.0603 \\
\hline & & 48.7015 & 0.9704 & & 64.2366 & 0.9642 & & 98.2090 & 0.8719 & \\
\hline & \multirow{3}{*}{6.976} & 9.77569 & 1.1006 & 1.0874 & 10.8202 & 1.1009 & 1.0859 & 16.5426 & 1.1023 & 1.0784 \\
\hline & & 29.5876 & 10.0856 & 0.0496 & 33.9805 & 8.1068 & 0.0617 & 46.078 & 6.5385 & 0.0765 \\
\hline & & 45.2354 & 0.9537 & & 52.4332 & 0.9750 & & 76.5482 & 0.9554 & \\
\hline \multirow{9}{*}{10} & \multirow{3}{*}{3.488} & 11.3312 & 1.1026 & 1.0763 & 16.3907 & 1.1006 & 1.0874 & 28.2533 & 1.101 & 1.0858 \\
\hline & & 34.6135 & 6.7413 & 0.0742 & 52.9193 & 6.4451 & 0.0776 & 80.9064 & 4.3367 & 0.1153 \\
\hline & & 54.9094 & 0.9943 & & 85.5128 & 0.9800 & & 106.715 & 0.9682 & \\
\hline & \multirow{3}{*}{4.651} & 10.7208 & 1.1006 & 1.0875 & 13.2560 & 1.1003 & 1.0893 & 25.0591 & 1.1010 & 1.0858 \\
\hline & & 32.1500 & 7.6240 & 0.0656 & 41.6299 & 6.3560 & 0.0787 & 78.6971 & 4.3367 & 0.1153 \\
\hline & & 51.0014 & 0.9714 & & 64.2366 & 0.9980 & & 128.3460 & 0.9682 & \\
\hline & \multirow{3}{*}{6.976} & 9.68588 & 1.1004 & 1.0886 & 11.0218 & 1.1002 & 1.0902 & 17.3238 & 1.1003 & 1.0894 \\
\hline & & 30.1388 & 10.2513 & 0.0488 & 35.2583 & 7.4006 & 0.0676 & 58.0356 & 6.8835 & 0.0726 \\
\hline & & 46.5053 & 0.9820 & & 53.9052 & 0.9833 & & 87.1058 & 0.9608 & \\
\hline \multirow{9}{*}{100} & \multirow{3}{*}{3.488} & 11.1240 & 1.1005 & 1.0884 & 15.5077 & 1.1020 & 1.0798 & 26.0014 & 1.1044 & 1.0669 \\
\hline & & 32.7490 & 6.5204 & 0.0767 & 47.3716 & 6.2766 & 0.0797 & 80.9064 & 6.4616 & 0.0774 \\
\hline & & 51.4743 & 0.9742 & & 76.5482 & 0.9764 & & 133.173 & 0.9714 & \\
\hline & \multirow{3}{*}{4.651} & 9.9578 & 1.1108 & 1.0340 & 12.5419 & 1.1025 & 1.0770 & 19.7132 & 1.1009 & 1.0858 \\
\hline & & 30.7002 & 7.3106 & 0.0684 & 39.3874 & 6.1148 & 0.0818 & 67.2702 & 6.4106 & 0.0780 \\
\hline & & 46.0780 & 0.9686 & & 61.3398 & 0.9950 & & 109.71 & 0.9493 & \\
\hline & \multirow{3}{*}{6.976} & 10.0501 & 1.1036 & 1.0712 & 10.4281 & 1.1002 & 1.0897 & 15.6515 & 1.1002 & 1.0899 \\
\hline & & 31.5621 & 10.5259 & 0.0475 & 33.6683 & 7.6248 & 0.0656 & 49.153 & 6.3935 & 0.0782 \\
\hline & & 48.7015 & 0.9845 & & 50.0687 & 0.9604 & & 80.1632 & 0.9374 & \\
\hline \multirow{9}{*}{1000} & \multirow{3}{*}{3.488} & 11.5423 & 1.1004 & 1.0886 & 17.8102 & 1.1017 & 1.0817 & 29.0465 & 1.1022 & 1.0789 \\
\hline & & 34.6135 & 7.0716 & 0.0707 & 51.9515 & 6.4217 & 0.0779 & 94.6497 & 7.3796 & 0.0678 \\
\hline & & 54.9094 & 0.9714 & & 83.1777 & 0.9819 & & 151.54 & 0.9971 & \\
\hline & \multirow{3}{*}{4.651} & 11.3312 & 1.1061 & 1.0575 & 13.3789 & 1.1035 & 1.0714 & 25.0591 & 1.1049 & 1.0643 \\
\hline & & 32.7490 & 8.7476 & 0.0572 & 40.4932 & 6.0509 & 0.0826 & 79.4268 & 6.5957 & 0.0758 \\
\hline & & 50.0687 & 0.9863 & & 60.7763 & 0.9938 & & 125.999 & 0.9856 & \\
\hline & \multirow{3}{*}{6.976} & 13.8820 & 1.1031 & 1.0737 & 11.7573 & 1.1013 & 1.0836 & 17.6466 & 1.1012 & 1.0841 \\
\hline & & 42.0159 & 10.0053 & 0.0500 & 35.9151 & 7.5780 & 0.0660 & 50.0687 & 6.5808 & 0.0760 \\
\hline & & 66.0399 & 0.9789 & & 55.4184 & 0.9718 & & 81.6565 & 0.9815 & \\
\hline
\end{tabular}


Table 2. Effect of the duration of pre-loading to the transmissibility

\begin{tabular}{|c|c|c|c|c|c|c|c|}
\hline $\begin{array}{c}\text { Duration of } \\
\text { Pre - } \\
\text { Loading } \\
{[\mathrm{h}]} \\
\end{array}$ & $\begin{array}{c}\text { Static load } \\
{[\mathrm{kPa}]}\end{array}$ & $\begin{array}{c}\text { Peak } \\
\text { Transmissibility } \\
\text { of PE25 }\end{array}$ & $\begin{array}{l}\text { Average } \\
\text { values }\end{array}$ & $\begin{array}{c}\text { Peak } \\
\text { Transmissibility } \\
\text { of PE30 }\end{array}$ & $\begin{array}{l}\text { Average } \\
\text { values }\end{array}$ & $\begin{array}{c}\text { Peak } \\
\text { Transmissibility } \\
\text { of PXPE }\end{array}$ & $\begin{array}{c}\text { Average } \\
\text { values }\end{array}$ \\
\hline 1 & 3.488 & 6.5726 & \multirow{3}{*}{8.1226} & 6.0573 & \multirow{3}{*}{6.84524} & 8.0871 & \multirow{3}{*}{7.6400} \\
\hline 1 & 4.651 & 7.7097 & & 6.3715 & & 8.2944 & \\
\hline 1 & 6.976 & 10.0856 & & 8.1068 & & 6.5385 & \\
\hline 10 & 3.488 & 6.7413 & \multirow{3}{*}{8.2055} & 6.4451 & \multirow{3}{*}{6.733889} & 4.3367 & \multirow{3}{*}{6.1224} \\
\hline 10 & 4.651 & 7.6240 & & 6.3560 & & 6.8835 & \\
\hline 10 & 6.976 & 10.2513 & & 7.4006 & & 7.1471 & \\
\hline 100 & 3.488 & 6.5204 & \multirow{3}{*}{8.1190} & 6.2766 & \multirow{3}{*}{6.672063} & 6.4616 & \multirow{3}{*}{6.4219} \\
\hline 100 & 4.651 & 7.3106 & & 6.1148 & & 6.4106 & \\
\hline 100 & 6.976 & 10.5260 & & 7.6248 & & 6.3935 & \\
\hline 1000 & 3.488 & 7.0716 & \multirow{3}{*}{8.6082} & 6.4217 & \multirow{3}{*}{6.683546} & 7.3796 & \multirow{3}{*}{6.8520} \\
\hline 1000 & 4.651 & 8.7476 & & 6.0509 & & 6.5957 & \\
\hline 1000 & 6.976 & 10.0053 & & 7.5780 & & 6.58084 & \\
\hline & & & 8.2638 & & 6.7337 & & 6.7591 \\
\hline
\end{tabular}

\section{CONCLUSIONS}

Polyethylene is a widely used material for protective packaging in distribution. This paper provides important properties of cross-linked and non-cross-linked polyethylene foam relevant to their application after different storage time and offers advice on the cushioning design of packaging through the measured resonant frequencies and the calculated damping ratios. The results show that PE25 and PE30 are less influenced by the duration of pre-loading compared to XPE. Over 86 $\mathrm{Hz}$ for non-cross-linked PE and over $126 \mathrm{~Hz}$ for crosslinked PE the frequency is in the attenuation zone at all investigated static loads and duration.

The results of this paper provide new information on cushion materials for PE and XPE foams for packaging engineers, which can help obtain optimal packaging solutions that give suitable protection to the products and can reduce the packaging mass used in practice.

\section{REFERENCES}

[1] Hanlon, J., Kelsey, R.,Forcinio, H. Handbook of Package Engineering, 3rd edn., Technomic Publishing Company, Inc.: Boca Raton, Florida, 1998.

[2] Yam, K. L. The Wiley encyclopedia of packaging technology, 2nd ed., John Wiley \& Sons, New York, 2010.

[3] Guo, Y., Xu, W., Fu, Y. and Wang, H.: Dynamic shock cushioning characteristics and vibration transmissibility of X-PLY corrugated paperboard. Shock Vib, Vol. 18, pp. 525-535, 2011.https://doi.org/10.3233/SAV-2010-0559

[4] Sherman, M. Medical Device Packaging Handbook, 1st ed.; CRC Press, New York,1988.

[5] Böröcz, P. and Singh, S.P.: Measurement and analysis of delivery van vibration levels to simulate package testing for parcel delivery in Hungary. PackagTechnol Sci, Vol. 31, No 5,pp. 342-352., 2018.https://doi.org/10.1002/pts.2327

[6] Ilic, Z., Rašuo, B., Jovanovic, M., Jovicic,S., Tomic, L., Jankovic, M. and Petrašinovic, D.: The efficiency of passive vibration damping on the pilot seat of piston propeller aircraft, Measurement, Vol.
95, pp. 21-32, 2017. doi: 10.1016/j.measurement. 2016.09.042

[7] Kolich, M., Essenmacher, S., D. and McEvoy, J., T.: Automotive seating: The effect of foam physical properties on occupied vertical vibration transmissibility, J SoundVib, Vol. 281, No. 1, pp. 409-416, 2005.doi: 10.1016/j.jsv.2004.03.058

[8] Zhang, X., Qiu, Y., and Griffin, M., J.: Transmission of vertical vibration through a seat: Effect of thickness of foam cushions at the seat pan and the backrest, Int J IndErgonom, Vol. 48, No. July, pp. 36-45, https://doi.org/10.1016/j.ergon.2015.03.006

[9] Blanchard, C., Weisser, T., Barbeau, R., Aubry, E. and Mallet-da Costa., A.: Study of the static and dynamic behaviour of PU foam: from the material sample to the automotive seat..Surveillance, Vishno and AVE conferences, Jul 2019, Lyon, pp. 1-10. ffhal-02188575

[10] McGee, S. D., Batt, G. S., Gibert, J. M. and Darby, D. O.: Predicting the effect of temperature on the shock absorption properties of polyethylene foam. PackagTechol Sci,Vol. 30, No. 8,pp. 477-494. 2017.https://doi.org/10.1002/pts.2208

[11] Li, G., Rouillard, V. andSek, M. A.: Evaluation of static and dynamic cushioning properties of polyethylene foam for determining its cushion curves. PackagTechol Sci, Vol.28, No. 1, pp. 47-57, 2015.https://doi.org/10.1002/pts.2090

[12] Paulin, K., Batt, G. andDaum M.: Statistical analysis of the stress-energy methodology applied to cushion curve determination. J Test Eval,Vol. 41, No.3,pp. 409-416, 2013,.doi:10.1520/JTE20120155

[13] Gibert, J. and Batt, G.: Impact oscillator model for the prediction of dynamic cushion curves of open cell foams. PackagTechnol Sci, Vol.28, No. 3, pp. 227-239, 2015.https://doi.org/10.1002/pts.2100

[14] Marcondes, J., Hatton, K.,,Graham, J. andSchueneman, H.: Effect of temperature on the cushioning properties of some foamed plastic materials. PackagTechnol Sci, Vol.16, No. 2, pp. 69-76, 2003.https://doi.org/10.1002/pts.614 
[15] Csavajda, P. and Böröcz, P.: Effect of Temperature Changes on the Vibration Transmissibility of XPE and PE Packaging Cushioning Material. Appl. Sci, Vol. 11, No. 482, pp. 1-18, 2021. https:// doi.org/10.3390/app11020482

[16] Guo, Y. Zhang, J.: Shock absorbing characteristics and vibration transmissibility of honeycomb paperboard. Shock Vib. Vol 11, pp. 521-531, 2003, doi: $10.1155 / 2004 / 936804$

[17] Avalle, M., Belingardi, G. and Montanini, R.: Characterization of polymeric structural foams under compressive impact loading by means of energy-absorption diagram, Int $\mathrm{J}$ ImpactEng, Vol. 25, No. 5, pp. 455-472, 2001. doi: 10.1016/S0734743X(00)00060-9

[18] Saha, M.C., Mahfuz, H., Chakravarty, U.K., Uddin, M., Kabir, Md. E. and S. Jeelani: Effect of density, microstructure, and strain rate on compression behavior of polymeric foams, Mat SciEng A-Struct, Vol. 406, No. 1-2, pp. 328-336,2005. doi: 10.1016/j.msea.2005.07.006

[19] Chen, W., Hao, H., Hughes, D., Shi, Y., Cui, J. and $\mathrm{Li}, \mathrm{Z}$.: Static and dynamic mechanical properties of expanded polystyrene, Mater Design, Vol. 69, pp. 170-180, 2015. Doi: 10.1016/j.matdes.2014.12.024

[20] Parker, A.J.: A Method of Characterisation of the Nonlinear Vibration Transmissibility of Cushioning Materials, Ph.D. Thesis, School of Architectural, Civil and Mechanical Engineering, Victoria University, Melbourne, 2007. Available online: http://vuir.vu.edu.au/id/eprint/1531 (accessed on 12January 2021).

[21] Batt, G.: Primary Resonance Behavior of Expanded Polymer Cushion Material under Low-Intensity Harmonic Excitations, Ph.D. Thesis, Clemson University, Clemson, 2013. Available online: https://tigerprints.clemson.edu/all dissertations/126 0/ (accessed on 12 January 2021)

[22] Brandenburg, R.K., Lee, J.J.:Fundamentals of Packaging Dynamics. L.A.B. Equipment, Itasca, 2001.

[23] Goodwin, D. and Young, D.: Protective Packaging for Distribution, DEStech Publications, Lancaster, 2011.

[24]Guo, Y. and Zhang, J.: Shock absorbing characteristics and vibration transmissibility of honeycomb paperboard, Shock Vib, Vol. 11, 521-

531, 2004.https://doi.org/10.1155/2004/936804

\section{NOMENCLATURE}

$$
\begin{array}{ll}
T_{r} & \text { Transmissibility value } \\
f_{f} & \text { Forcing frequency } \\
f_{n} & \text { Natural frequency }
\end{array}
$$

\section{Greek symbols}

$\xi \quad$ Damping ratio

\section{ЕКСПЕРИМЕНТАЛНО ПРОУЧАВАЊЕ ПРЕНОСИВОСТИ ВИБРАЦИЈА ПРИ ПРЕДОПТЕРЕТЕЊУ ХРЕ И РЕ МАТЕРИЈАЛА ЗА АМОРТИЗАЦИЈУ И ПАКОВАЊЕ}

\section{П. Чавајда, П. Берец}

Већина производа за транспорт осетљива је на удар и вибрације. Како би се спречило оштећење производа користе се разни материјали за амортизацију удара и вибрација. У процесу пројектовања система за заштиту паковања инжењери користе материјале са карактеристикама амортизације и преносивости вибрација. Међутим, паковани производи остају у складишту краће или дуже време, због чега долази до предоптерећења материјала за амортизацију а тиме и до промене његових параметара. Циљ рада је да се изврши евалуација преносивости вибрација код ХРЕ и РЕ материјала у различитим условима складиштења (предоптерећења) и статичког оптерећења. Узета су 4 периода трајања предоптерећења $(1,10,100$ и 1000 сати) за три статичка оптерећења (3488, 4651, 6976 кРа) и потом су одређене вршне фреквенције одзива и преносивост вибрација, као и однос пригушења, при 0,5 ост/мin синусне вибрације. Резултати показују да је утицај предоптерећења РЕ материјалом минималан, али да ХРЕ материјал може да има утицаја на резонантне фреквенције. Налази истраживања су од помоћи инжењерима који се баве проблемом паковања у бољем разумевању механизма наведених материјала и пројектовању адекватних заштитних система паковања производа. 